\title{
Faktor yang Berhubungan dengan Keaktifan Kunjungan Lanjut Usia ke Posyandu Lansia
}

\section{Factors Related to The Activity of Elderly Visit in Integrated Health Post}

\author{
Sunarti Hanapi* dan Zul Adhayani Arda \\ Ilmu Kesehatan Masyarakat, Fakultas Kesehatan Masyarakat, Universitas Gorontalo \\ *email: sunarti82hanapi@gmail.com
}

\begin{abstract}
Aging population carries various implications from social, economic, justice, political and especially health aspects. Health problems were one of the main problems for elderly population, because relates to human physical deterioration that occurs naturally as well as the concerns of subsistence. One of the efforts to handle health problems for elderly is through the elderly community health care. The aim of study to determine the factors associated with elderly visit to elderly community health care. The type of research was used analytic observational with cross sectional design. The sample in this study were the partial of elderly who live in area of Bongomeme Health Center, Tibawa Health Center, Batudaa Health Center and Limboto Barat Health Center in Gorontalo District as many as 349 people. This research was conducted in December 2017 - February 2018. The results showed that there was a significant relationship between knowledge ( $p$ value $=0,006$ ) with elderly visit to Elderly Community Health Care. However, there was not significant relationship between cadre's liveliness ( $p$ value $=0,871$ ), family support ( $p$ value $=$ 0,642 ) and type of services ( $p$ value $=0,225$ ) with elderly visit to Elderly Community Health Care in some Health Center in Gorontalo District. It was recommended to all organizers especially the Health Center to place the Health Care in a strategic position and not too far from the elderly's residence. To make it easily accessible by elderly.
\end{abstract}

Keywords; elderly, health services, knowledge

\begin{abstract}
Abstrak
Populasi lanjut usia (Lansia) membawa berbagai implikasi dari aspek sosial, ekonomi, keadilan, politik terutama kesehatan. Masalah kesehatan adalah salah satu masalah utama bagi penduduk lanjut usia, karena berhubungan dengan masalah fisiologis yang terjadi secara alami serta kekhawatiran yang subsistensi. Salah satu upaya penanganan masalah kesehatan lansia adalah melalui perawatan kesehatan masyarakat lansia. Tujuan penelitian untuk menentukan faktor-faktor yang terkait dengan kunjungan lansia ke Posyandu Lansia. Jenis penelitian yang digunakan adalah observasional analitik dengan desain cross sectional study. Sampel dalam penelitian ini adalah sebagian lansia yang tinggal di wilayah kerja Puskesmas Bongomeme, Puskesmas Tibawa, Puskesmas Batudaa dan Puskesmas Limboto Barat di Kabupaten Gorontalo sebanyak 349 orang. Penelitian ini dilakukan pada bulan Desember 2017 - Februari 2018. Hasil penelitian menunjukkan bahwa ada hubungan yang signifikan antara pengetahuan ( $p$ value $=0,006$ ) dengan kunjungan lansia ke Posyandu Lansia. Namun, tidak ada hubungan yang signifikan antara keaktifan kader ( $p$ value $=$ $0,871)$, dukungan keluarga ( $p$ value $=0,642)$ dan jenis layanan $(p$ value $=0,225)$ dengan kunjungan lansia ke Posyandu Lansia di beberapa Puskesmas di
\end{abstract}


Kabupaten Gorontalo. Kepada semua penyelenggara Posyandu Lansia kiranya dapat menempatkan Posyandu pada posisi yang strategis dan tidak terlalu jauh dari rumah kelompok Lansia, untuk memudahkan akses Lansia berkunjung ke Posyandu Lansia.

Kata kunci; lansia, layanan kesehatan, pengetahuan

\section{PENDAHULUAN}

Lanjut usia (lansia) yaitu seseorang yang telah mencapai 60 tahun ke atas baik pria maupun wanita. Permasalahan kesehatan merupakan salah satu permasalahan utama penduduk lansia, karena terkait dengan kemunduran fisik manusia yang terjadi secara alamiah serta menyangkut pemenuhan kebutuhan hidup (Depkes RI, 2010).

Berdasarkan Riset Fasilitas Kesehatan (Rifaskes) tahun 2011 secara nasional persentase puskesmas yang memiliki posyandu lansia adalah $78,8 \%$. Provinsi dengan persentase puskesmas tertinggi yang memiliki posyandu lansia adalah Provinsi DI Yogyakarta $(100 \%)$ diikuti Jawa Tengah $(97,1 \%)$ dan Jawa Timur $(95,2 \%)$. Sedangkan persentase terendah ada di Papua (15\%), Papua Barat $(18,2 \%)$ dan Sulawesi Barat $(22,2 \%)$. Bila dilihat dari lokasi, persentase puskesmas di perkotaan yang memiliki posyandu lansia 80,9\%, sementara di pedesaan 78,3\% (KemenKes, 2013).

Posyandu adalah pusat kegiatan masyarakat dalam upaya pelayanan kesehatan dan keluarga berencana. Posyandu adalah pusat pelayanan keluarga berencana dan kesehatan yang dikelola dan diselenggarakan untuk dan oleh masyarakat dengan dukungan teknis dari petugas kesehatan. Pos Pelayanan Terpadu Lanjut Usia merupakan suatu forum komunikasi, alih tekhnologi dan pelayanan kesehatan oleh masyarakat dan untuk masyarakat yang mempunyai nilai stategis untuk pengembangan sumber daya manusia, khususnya Lanjut Usia. Posyandu ini untuk masyarakat usia lanjut di suatu wilayah tertentu yang sudah disepakati, yang digerakkan oleh masyarakat dimana mereka bisa mendapatkan pelayanan kesehatan Posyandu lansia merupakan pengembangan dari kebijakan pemerintah melalui pelayanan kesehatan bagi lansia yang penyelenggaraannya melalui program Puskesmas dengan melibatkan peran serta para lansia, keluarga, tokoh masyarakat dan organisasi sosial dalam penyelenggaraannya (Erfandi, 2008 ).

Pengetahuan merupakan salah satu faktor instrinsik yang mempengaruhi motivasi. Tingkat pengetahuan seseorang tidak selalu memotivasi perilaku logika, artinya pengetahuan yang baik (Lansia yang tahu tentang pengertian Posyandu, tujuan Posyandu, manfaat posyandu, bentuk pelayanan Posyandu, dan sasaran Posyandu) tidak selalu memiliki perilaku yang benar dalam hal ini pengetahuan tentang posyandu yang baik belum tentu mau berkunjung ke posyandu (Kurniasari, 2013). Pengetahuan lansia yang kurang tentang Posyandu Lansia mengakibatkan kurangnya pemahaman lansia dalam pemanfaatan posyandu lansia. Keterbatasan pengetahuan ini akan mengakibatkan dampak yang kurang baik dalam pemeliharaan kesehatannya (Kurniasari, 2013).

Keaktifan kader adalah tindakan nyata kader dalam melaksanakan tugastugas kegiatan posyandu baik sebelum kegiatan posyandu, selama kegiatan posyandu dan setelah kegiatan posyandu. Kepuasan lansia merupakan tingkat perasaan lansia setelah membandingkan antara kinerja atau hasil yang dirasakan (pelayanan yang diterima dan dirasakan) dengan yang diharapkannya (Dianasari, 2011).

Di Provinsi Gorontalo untuk kelompok usia tua, mengalami peningkatan dari tahun sebelumnya yakni persentase penduduk laki - laki 0,64\% ditahun 
2013 meningkat menjadi 0,65\% ditahun 2014, sedangkan perempuan 0,96\% ditahun 2013 meningkat menjadi 1,08\% di tahun 2014. Hal ini dapat diartikan sebagai peningkatan kondisi kesehatan dan kesejahteraan penduduk, dapat pula dimaknai sebagai beban tanggungan kelompok usia dewasa karena kelompok usia tua termasuk dalam kelompok tidak produktif (Profil Dikes Provinsi Gorontalo, 2014).

Data dari Dinas Kesehatan Kabupaten Gorontalo bahwa pada kelompok usia lanjut (USILA), juga mengalami peningkatan dari tahun sebelumnya yakni pada tahun 2016 sebanyak 5.328 lansia dan meningkat pada tahun 2017 sebanyak 9.829 lansia yang berkunjung ke posyandu lansia (Profil Dikes Kabupaten Gorontalo, 2017). Berdasarkan uraian tersebut, sehingga penelitian ini bertujuan untuk menganalisis faktor - faktor yang berhubungan dengan kunjungan kelompok lansia ke Posyandu Lansia di beberapa Wilayah Puskesmas Kabupaten Gorontalo.

\section{METODE}

Jenis penelitian yang dilakukan adalah observasional analitik dengan desain cross sectional study. Waktu penelitian adalah bulan Desember tahun 2017 Februari tahun 2018 yang dilaksanakan di Beberapa Puskesmas wilayah Kabupaten Gorontalo. Populasi dalam penelitian ini adalah seluruh lansia yang ada di wilayah kerja Puskesmas Bongomeme, Puskesmas Tibawa, Puskesmas Batudaa, Puskesmas Limboto Barat dengan jumlah populasi 3.765 orang. Teknik pengambilan sampel dengan cara proportional stratified random sampling. Variable penelitian meliputi kunjungan lansia ke posyandu lansia, pengetahuan lansia, tingkat keaktifan kader, dukungan keluarga, dan jenis pelayanan posyandu. Analisis data menggunakan analisis univariat dan bivariat, pada analisis bivariat menggunakan uji chi square pada derajat kepercayaan $95 \%$ dengan derajat kemaknaan sebesar $5 \%$ atau $a=0,05$.

\section{HASIL DAN PEMBAHASAN}

\section{Analisis Karakteristik Subyek Penelitian}

Gambaran karakteristik umur, jenis kelamin dan pekerjaan lansia yang menjadi subjek penelitian sebagaimana ditunjukkan pada Tabel 1. Dari Tabel tersebut dapat dijelaskan bahwa dilihat dari Umur paling banyak terdistribusi pada usia 60-70 tahun yaitu sebanyak 200 orang $(33,5 \%)$, untuk jenis kelamin lebih banyak terdistribusi pada jenis kelamin perempuan yaitu sebanyak 234 orang $(67,0 \%$, sedangkan Variabel pekerjaan lebih banak terdistribusi pada yang tidak bekerja.

Tabel 1. Gambaran Karakteristik, Umur, Jenis Kelamin dan Pekerjaan Lanjut Usia di beberapa Puskesmas Wilayah Kabupaten Gorontalo

\begin{tabular}{lcc}
\hline \multicolumn{1}{c}{ Variabel } & \multicolumn{2}{c}{ Jumlah } \\
\cline { 2 - 3 } & $\mathrm{n}$ & $\%$ \\
\hline Umur Responden (thn) & 117 & 33,5 \\
45-59 & 200 & 57,3 \\
$60-70$ & 32 & 9,2 \\
$\quad$ 70 & & \\
Jenis kelamin & 115 & 33,0 \\
$\quad$ Laki-laki & 234 & 67,0 \\
$\quad$ Perempuan & & \\
Pekerjaan & 134 & 38,4 \\
$\quad$ Bekerja & 215 & 61,6 \\
Tidak bekerja & & \\
\hline
\end{tabular}


Berdasarkan hasil penelitian menunjukkan bahwa kelompok kategori umur yang paling banyak adalah 60 - 70 tahun yakni 57,3\%. Hasil penelitian ini berbeda dengan hasil penelitian Hatta dkk (2018) yang mendapatkan bahwa kelompok lansia yang paling banyak adalah usia 60 - 90 tahun $(88,4 \%)$, adanya perbedaan hasil penelitian ini karena penggunakan klasifikasi umur yang berbeda. Analisis jenis kelamin menunjukkan paling banyak perempuan yakni $67,0 \%$, berbeda dengan penelitian sebelumnya yang mendapatkan kategori lansia laki - laki yang paling tinggi yakni 78,5\% (Hatta dkk, 2018).

\section{Pengetahuan, Keaktifan Kader, Dukungan Keluarga dan Jenis Pelayanan Posyandu Lansia}

Analisis deskriptif pada Tabel 2 menunjukkan bahwa pengetahuan kurang sebanyak 62,7\% yang kurang aktif berkunjung ke Posyandu Lansia. Berdasarkan analisis variabel keatifan kader menunjukkan terdapat $75,6 \%$ kader yang kurang aktif dengan tingkat kunjungan kurang aktif ke Posyandu pada Lansia. Analisis variabel dukungan keluarga menunjukkan $77,2 \%$ kategori dukungan keluarga kurang yang kurang aktif berkunjung ke Posyandu Lansia. Berdasarkan analisis variabel jenis pelayanan menunjukkan $80,6 \%$ jenis pelayanan kurang lengkap dengan kunjungan lansia yang kurang aktif ke Posyandu Lansia.

Tabel 2. Hubungan antara Pengetahuan, Keaktifan Kader, Dukungan Keluarga dan Jenis Pelayanan dengan Keaktifan Kunjungan Lansia ke Posyandu Lansia

\begin{tabular}{|c|c|c|c|c|c|c|c|}
\hline \multirow{2}{*}{ Variabel } & \multicolumn{4}{|c|}{ Keaktifan kunjungan lansia } & \multicolumn{2}{|c|}{ Total } & \multirow[b]{2}{*}{ p Value } \\
\hline & \multicolumn{2}{|c|}{$\begin{array}{l}\text { Kurang aktif } \\
\text { berkunjung }\end{array}$} & \multicolumn{2}{|c|}{$\begin{array}{c}\text { Aktif } \\
\text { berkunjung }\end{array}$} & $\mathrm{n}$ & $\%$ & \\
\hline \multicolumn{8}{|l|}{ Pengetahuan } \\
\hline Kurang & 42 & 62,7 & 25 & 37,3 & 67 & 100 & 0,006 \\
\hline Cukup & 224 & 79,4 & 58 & 20,6 & 282 & 100 & \\
\hline \multicolumn{8}{|l|}{ Keaktifan kader } \\
\hline Kurang aktif & 133 & 75,6 & 43 & 24,4 & 176 & 100 & 0,871 \\
\hline Aktif & 133 & 76,9 & 40 & 23,1 & 173 & 100 & \\
\hline \multicolumn{8}{|l|}{ Dukungan keluarga } \\
\hline Kurang dukungan & 173 & 77,2 & 51 & 22,8 & 224 & 100 & 0,642 \\
\hline Ada dukungan & 93 & 74,4 & 32 & 25,6 & 125 & 100 & \\
\hline \multicolumn{8}{|l|}{ Jenis pelayanan } \\
\hline Kurang lengkap & 87 & 80,6 & 21 & 19,4 & 108 & 100 & 0,255 \\
\hline Lengkap & 179 & 74,3 & 62 & 25,7 & 241 & 100 & \\
\hline
\end{tabular}

Pengetahuan adalah faktor instrinsik yang mempengaruhi motivasi. Tingkat pengetahuan seseorang tidak selalu memotivasi perilaku logika, artinya pengetahuan yang baik (Lansia yang tahu tentang pengertian Posyandu, tujuan Posyandu, manfaat Posyandu, bentuk pelayanan Posyandu, dan sasaran Posyandu) tidak selalu memiliki perilaku yang benar dalam hal ini pengetahuan tentang posyandu yang baik belum tentu mau berkunjung ke posyandu (Kurniasari, 2013). Berdasarkan hasil analisis bivariat dengan mengunakan uji statistik chi square ada hubungan yang signifikan antara pengetahun dengan kunjungan lanjut usia ke posyandu lansia dengan nilai $\mathrm{p}$ value $=0,006$. Pada hasil penelitian yang dilakukan di beberapa Puskesmas di wilayah Kabupaten Gorontalo menunjukkan bahwa banyak lansia yang berpengetahuan cukup akan tetapi tidak aktif berkunjung, hal ini disebakan oleh masyarakat masih banyak yang menyikapinya secara negatif, sebab bagi mereka Posyandu hanyalah untuk anak balita bukanlah bagi orang-orang tua. 
Ada beberapa faktor yang mempengaruhi pengetahuan yaitu tingkat pendidikan, informasi yang diperoleh, pengalaman dan sosial ekonomi. Pengetahuan Lansia akan manfaat Posyandu ini dapat diperoleh dari pengalaman pribadi dalam kehidupan sehari-harinya. Lansia yang menghadiri kegiatan Posyandu, maka Lansia akan mendapatkan penyuluhan tentang cara hidup sehat dengan segala keterbatasan atau masalah kesehatan yang melekat pada mereka. Pengalaman tersebut membuat pengetahuan Lansia menjadi meningkat, yang menjadi dasar pembentukan sikap dan dapat mendorong minat atau motivasi mereka untuk selalu mengikuti kegiatan posyandu lansi (Kurniasari, 2013).

Keaktifan kader yang dimaksud adalah kader dalam melaksanakan tugastugas kegiatan posyandu baik sebelum kegiatan posyandu, selama kegiatan posyandu dan setelah kegiatan posyandu. Dimana kepuasan lansia merupakan tingkat perasaan lansia setelah membandingkan antara kinerja atau hasil yang dirasakan (pelayanan yang diterima dan dirasakan) dengan yang diharapkannya (Dianasari, 2011). Berdasarkan hasil analisis bivariat dengan mengunakan uji statistik chi square diperoleh nilai $p$ value $=0,871$ yang menujukkan bahwa tidak ada hubungan antara keaktifan kader dengan kunjungan lanjut usia ke Posyandu Lansia. Penelitian ini tidak sejalan dengan penelitian yang dilakukan oleh Hikmawati (2014) yang menyatakan bahwa ada hubungan antara peran kader dengan keaktifan lansia mengikuti Posyandu lansia $\left(\mathrm{X}^{2}=13,605 ; \mathrm{p}=0,0001\right)$, artinya semakin baik dan positif peran kader yang dimiliki lanjut usia tersebut maka semakin baik dan aktif pula mereka dalam mengikuti kegiatan di Posyandu Lansia.

Dukungan keluarga adalah keluarga yang mendorong minat atau kesediaan lansia untuk mengikuti kegiatan Posyandu Lansia. Keluarga bisa menjadi motivator kuat bagi lansia apabila selalu menyempatkan diri untuk mendampingi atau mengantar lansia ke Posyandu, mengingatkan lansia jika lupa jadwal Posyandu dan berusaha membantu mengatasi segala permasalahan bersama lansia (Erfandi, 2008). Berdasarkan hasil analisis bivariat dengan mengunakan uji statistik chi square diperoleh nilai $p$ value $=0,871$ yang menujukkan bahwa tidak ada hubungan antara dukungan keluarga dengan kunjungan lanjut usia ke Posyandu Lansia. Penelitian ini tidak sejalan dengan penelitiian yang dilakukan oleh Tajudin (2015) yang menyatakan bahwa ada hubungan antara dukungan keluarga dengan keaktifan lansia dengan nilai $\mathrm{p}$ $(0,013)<(0,05)$. Hasil penelitian ini menunjukkan bahwa ada $77,2 \%$ lansia tidak aktif ke Posyandu karena kurang dukunga dari keluarga demikian juga untuk yang ada dukungan dari keluarga masih banyak yang kurang aktif untuk berkunjung ke Posyandu meskipun mereka mendapatkan dukungan dari keluarga, hal ini desebabkan oleh faktor ekonomi dan jarak.

Pelayanan Posyandu merupakan pelayanan kesehatan di Posyandu lanjut usia meliputi pemeriksaan Kesehatan fisik dan mental emosional yang dicatat dan dipantau dengan Kartu Menuju Sehat (KMS) untuk mengetahui lebih awal penyakit yang diderita (deteksi dini) atau ancaman masalah kesehatan yang dihadapi. Jenis pelayanan kesehatan yang diberikan kepada usia lanjut di Posyandu Lansia seperti pemeriksaan aktivitas kegiatan sehari-hari meliputi kegiatan dasar dalam kehidupan seperti makan/minum, berjalan, mandi, berpakaian, naik turun tempat tidur, buang air besar/kecil dan sebagainya (Depkes, 2010). Hasil analisis data dengan menggunakan uji statistik chi square diperoleh nilai $p$ value $=0,255(>0,05)$ yang berarti tidak ada hubungan antara jenis pelayanan dengan keaktifan kunjungan lansia ke posyandu lansia. Pada penelitian yang dilakukan di beberapa Puskesmas di wilayah Kabupaten Gorontalo diperoleh bahwa jenis pelayanan yang diberikan sebahagian besar sudah lengkap namun tetap saja masih banyak yang kurang aktif datang 
berkunjung ke Posyandu, hal ini di sebabkan oleh faktor aksebilitas dimana jarak antara tempat pelayanan Posyandu dengan tempat tinggal lansia cukup jauh. Penelitian ini sejalan dengan penelitian yang dilakukan oleh Sukmawati (2015) yang menyatakan bahwa tidak ada hubungan antara fasilitas kesehatan dengan pemanfaatan Posyandu Lansia dengan nilai $p$ value sebesar 0.702 berarti $p$ value $>$ a $(0,05)$.

\section{PENUTUP}

Disimpulkan bahwa terdapat hubungan signifikan antara pengetahuan dengan keaktifan kunjungan lansia ke Posyandu Lansia, namun tidak ada hubungan keaktifan kader, dukungan keluarga dan jenis pelayanan dengan keaktifan kunjungan lansia ke Posyandu Lansia. Kepada pihak pelaksana kegiatan Posyandu khususnya pihak Puskesmas untuk menempatkan pelaksanaan Posyandu di posisi yang strategis dan tidak terlalu jauh dari tempat tinggal lansia yang jumlah lansianya banyak, agar memudahkan Lansia untuk menuju Posyandu.

\section{DAFTAR PUSTAKA}

Depkes RI. 2010. Pedoman pelatihan kader kelompok usia lanjut bagi petugas kesehatan. Depkes RI. Jakarta.

Dianasari. 2011. Faktor-faktor yang mempengaruhi kunjungan lanjut usia ke Posyandu lanjut usia. Naskah Publikasi. Fakultas Ilmu Kesehatan Universitas Muhammadiyah Surakarta.

Dikes Kabupaten Gorontalo. 2017. Profil Kesehatan Kabupaten Gorontalo. Dikes Kabupaten Gorontalo. Gorontalo.

Dikes Provinsi Gorontalo. 2014. Profil Kesehatan Provinsi Gorontalo. Dikes Provinsi Gorontalo. Gorontalo.

Erfandi. 2008. Pengelolaan Posyandu lansia. Tersedia dalam www.erfendiblogspot.com.

Hatta H, Pakaya R, Laiya M. 2018. Analisis determinan status gizi Lansia di Puskesmas Limboto Barat. Gorontalo journal of public health. Vol 1(1): 24 30.

Hikmawati L. 2014. Hubungan dukungan keluarga dan peran kader dengan keaktifan lanjut usia dalam mengikuti kegiatan di Posyandu Desa Pucangan. Naskah Publikasi :Fakultas Ilmu Kesehatan.

Kemenkes. 2013. Pedoman pembinaan kesehatan usia lanjut bagi petugas kesehatan. Kemenkes. Jakarta.

Kurniasari. 2013. Hubungan akses ke Posyandu, dukungan keluarga, dan keluhanfisik dengan keaktifan lansia mengikuti kegiatan Posyandu Puspasari Abadi V Di Gonilan Kartasura. Publikasi Ilmiah. Program Studi Keperawatan.

Sukmawati, dkk. 2015. Faktor yang berhubungan dengan perilaku lansia dalam memanfaatkan Posyandu Lansia di Wilayah Kerja Puskesmas Landono. Fakultas Kesehatan Masyarakat Universitas Halu Oleo. Kendari.

Tajudin. 2015. Faktor-faktor yang berhubungan dengan keaktifan lansia yang berkunjung ke posyandu lansia Kelurahan Parit Lalang di wilayah kerja Puskesmas Melintang Kota Pangkal pinang. Naskah Publikasi :Fakultas Ilmu Kesehatan. 